disputes based on the analysis of the Constitution and laws of Ukraine, decisions of the Constitutional Court of Ukraine and individual decisions of the European Court of Human Rights are studied.

It is established that the main novelties of the constitutional reform in the field of justice in Ukraine include the fact that the powers to control the execution of a court decision are fixed at the level of the provisions of the Basic Law of Ukraine; the amendments determined that the binding nature of a court decision extends not only to the territory of Ukraine; the responsibility for the execution of a court decision rests with the state, and control over this process rests with the court that rendered the decision.

It is determined that one of the effective means of ensuring the implementation of the constitutional principle of binding judicial decisions in administrative proceedings is judicial control. It is substantiated that strengthening judicial control over the execution of court decisions and giving the court the right to impose penalties for this purpose is a measure to ensure the constitutional right of citizens to judicial protection.

It is proved that increasing the efficiency, quality and quantity of executed court decisions in Ukraine, which have entered into force, will lead to the following positive results: increasing the authority of the judiciary and the state as a whole, as well as the level of trust in government agencies; affirmation of the principle of the rule of law, etc.

Keywords: constitutional guarantees, court decision, obligation to comply, administrative process.

DOI: 10.33766/2524-0323.92.215-223

УДК 342.924

Т. М. Малиновська,

кандидат юридичних наук, доцент, провідний науковий співробітник науково-дослідної лабораторії з проблем протидії злочинності Харківського національного університету внутрішніх справ (м. Харків, Україна) e-mail:malttn496@gmeil.com iDhttps:/ / orcid.org/0000-0002-7713-7617

\title{
ПРОБЛЕМИ ЗАБЕЗПЕЧЕННЯ ЕФЕКТИВНОГО СУДОВОГО ЗАХИСТУ ЖЕРТВ ДОМАШНЬОГО НАСИЛЬСТВА У СПРАВАХ ПРО АДМІНІСТРАТИВНІ ПРАВОПОРУШЕННЯ, ПЕРЕДБАЧЕНІ СТАТТЕЮ 173-2 КУПАП
}

У науковій статті розглянуті проблемні питання забезпечення ефективного судового захисту жертв домашнього насиљьства у справах про адміністративні правопорушення, передбачені ст. 173-2 КУпАП. Зауважено, що домашнє насильство є комплексною проблемою, що порушує цілу низку прав і свобод людини. Наголошено, що Україна належить до тих країн, у яких ще відсутня ефективна система захисту та надання допомоги жертвам домашнього насильства.

У науковій статті проведено аналіз судової практики у справах про адміністративні правопорушення, передбачені ст. 173-2КУпАП.

(C) Малиновська Т. М., 2020 
Ключові слова: домашнє насилля, права людини, адміністративна відповідальність, суд, захист.

Постановка проблеми. Домашнє насильство є комплексною проблемою, що порушує цілу низку прав і свобод людини, зокрема на життя, свободу, недоторканність, право жити вільно від приниження честі та гідності поводження тощо. Тому для подолання цієї складної проблеми кожна цивілізована країна повинна запровадити ефективну комплексну систему протидії домашнього насильства, яка складається із трьох основних елементів: профілактики насильства, притягнення до відповідальності кривдників та надання допомоги і захисту жертвам домашнього насильства.

Саме такій підхід до розв'язання проблеми пропонується Конвенцією Ради Свропи про запобігання насильству стосовно жінок і домашньому насильству та боротьбу із цими явищами, що підписана Україною 7 листопада 2011р.

3 огляду на цілі та зміст Конвенщії, можна стверджувати, що вона побудована навколо забезпечення безпеки та підтримки жертв домашнього насильства. Важливим положенням у цьому аспекті є ст. 5, що встановлює принцип «належної турботи» держави в ситуаціях домашнього насильства та насильства щодо жінок, який уперше на рівні міжнародного права був закладений у Загальній рекомендації № 19 Комітету ООН із ліквідації дискримінації щодо жінок. Відповідно до ст. 5, сторони Конвенщії зобов' язуються вживати всіх необхідних законодавчих та інших заходів, для того щоб з «належною турботою» попереджати, розслідувати, карати та забезпечувати компенсацію за акти насильства, що вчинені в приватній сфері [1]. Це означає, що кожна держава, що ратифікує Конвенцію, має зобов' язання діяти на випередження проблеми, тобто вживати всіх відповідних заходів щодо захисту прав людини та недопущення домашнього насильства.

У правовій державі, якою проголосила себе Україна, діє принщип верховенства права. Конституція України має найвищу юридичну силу. Усі нормативноправові акти приймаються на їі основі і повинні відповідати їй. Норми Конституції України є нормами прямої дії. Звернення до суду для захисту конституційних прав і свобод людини і громадянина грунтуються на підставі Конституції України.

Принцип законності полягає в єдиному порядку провадження по справі відповідної юрисдикції, дотриманні процесуальної форми та виконанні передбаченої процедури застосування закону.

О. М. Бандурка зауважує, що принщип законності полягає в тому, що «посадові особи ... зобов' язані виконувати вимоги законодавства в точній відповідності до їх змісту. Будучи принципом і методом суспільних відносин, режимом соціального життя, законність ... є складовою частиною механізму регулювання суспільних відносин, представляє собою обов' язкову умову правопорядку, державної і громадської дисципліни, важливий елемент демократії та культури» [2, с. 47]. Законність завжди означає відповідність поведінки (діяльності) суб' єктів суспільних відносин нормам права (закону). Водночас, на думку Г. Я. Наконечної, дотримання належним чином принципу законності в судовій діяльності може говорити про демократичність судової системи, а отже, і всієї країни в цілому, адже суд у своїй діяльності підкоряється виключно закону і діє у його межах [3, с. 61]. 
Законом України «Про запобігання та протидію домашньому насильству» визначені суб'єкти, що здійснюють заходи у сфері запобігання та протидії домашньому насильству. Зокрема до них віднесені й судові органи, яким надана вирішальна роль у системі запобігання та протидії домашньому насильству [4].

Надзвичайно важливою є роль суду щодо забезпечення безпеки та захисту жертв домашнього насильства від подалыших протиправних посягань через правильне застосування норм вітчизняного права у сфері протидії таким злочинам, зокрема притягнення до реальної відповідальності винних осіб, обмеження доступу кривдників до жертв, призначення відшкодування шкоди, завданої жертві протиправними діями з боку кривдника тощо [5, с. 51].

Аналіз останніх досліджень і публікацій. Фундаментальні основи сучасних теорій насильства були закладені в дослідженнях О. Бандурки, А. Благої, В. Вітвицької, О. Джужи, Л. Завадської, Л. Кормич, Л. Крижної, Н. Лавриненко, І. Лавринчука, К. Левченко, Л. Леонтьєвої, Л. Левицької, О. Матвієнко, Т. Мінки та інших. Саме вказаними вченими сформовано низку принципово важливих положень та рекомендацій щодо профілактики та протидії домашньому насиллю. Водночас у сучасній Україні проблематика домашнього насильства не втрачає своєї актуальності й потребує подальшого дослідження та розробки заходів протидії цьому явищу у сфері забезпечення ефективного судового захисту жертв домашнього насильства.

Формулювання цілей. Метою статті є аналіз практики розгляду справ про накладання адміністративних стягнень за вчинення домашнього насильства.

Завданням статті є виявлення ступеню обгрунтованості позищій суду щодо притягнення до відповідальності осіб за вчинення домашнього насильства, визначення проблемних питань розгляду судами проваджень про адміністративні правопорушення, передбачені ст. 173-2 КУпАП.

Наукова новизна дослідження зумовлена потребою визначення та дослідження актуальних проблемних питань, пов'язаних із забезпеченням ефективного судового захисту жертв домашнього насильства.

Виклад основного матеріалу. Домашнє насильство є однією з розповсюджених форм порушення прав людини. У багатьох випадках такі протиправні дії проти когось із членів родини супроводжуються актами агресії, приниження та жорстокої поведінки. Подібні дії з боку насильника приводять до негативного фізичного, психічного та соціального стану здоров'я постраждалої особи чи кількох осіб, членів цієї родини. Як правило, найбільше страждають від домашнього насильства жінки, діти та люди похилого віку.

Необхідність ефективної протидії та запобіганню домашньому насиллю зумовлена тим, що сьогодні випадки вчинення цього протиправного діяння в Україні стають усе більш масштабними. Так, за даними громадської організації «Ла Страда - Украӥна», на Національну гарячу лінію з попередження домашнього насильства, торгівлі людьми та гендерної дискримінації за перше півріччя 2019 року надійшло17341 звернень і 6157 - на дитячу лінію відповідно [6]. У 2020 року в умовах карантину тільки за перший тиждень кількість звернень на «гарячу лінію» зросла на 50 \%, ніж зазвичай [7]. Як правило, найбільш уразливими є сім'ї з низьким 
рівнем доходу, адже умови карантину призвели до економічного спаду і безробіття, що є додатковим подразником і стресом у родині.

Як повідомив керівник Управління дільничних офіцерів поліції Департаменту превентивної діяльності Національної поліції С. Альошкін, до поліції щодня надходить понад 1,5 тисячі звернень про насилля. У березні 2020 року до адміністративної відповідальності за домашне насильство в Україні притягнуто 11200 громадян, одночасно як у 2019 році було вчинено 109345 адміністративних правопорушень, передбачених ст. 173-2 КУпАП. Тобто, торік середньомісячна цифра таких порушень складала 9112 [8].

Значним недоліком системи протидії домашньому насильству в Україні $є$ недосконалий механізм притягнення до відповідальності за вчинення домашнього насильства, складність у доведенні винуватості осіб, які вчиняють домашнє насильство, та наслідків такого насильства.

Адміністративне законодавство України містить спеціальну норму, що закріплює адміністративну відповідальність за вчинення домашнього насильства, насильства за ознакою статі, невиконання термінового заборонного припису або неповідомлення про місце свого тимчасового перебування. Названі дії кваліфікуються за ст. 173-2 Кодексу України про адміністративні правопорушення. Відповідно до ст. 221 КУпАП, справи про адміністративні правопорушення, передбачені ст. 173-2 КУпАП, розглядають судді районних, районних у місті, міських чи районних судів. Відповідно до ч. 2 ст. 277 КУпАП, справи про адміністративні правопорушення, передбачені ст. 173-2 КУпАП, розглядаються протягом доби. За результатами розгляду справи про адміністративне правопорушення, передбачене статтею 173-2 КУпАП, суд (суддя) виносить постанову по справі: 1) про накладення адміністративного стягнення; 2) про застосування заходів впливу, передбачених ст. 24 КУпАП (громадські роботи, адміністративний арешт); 3) про закриття справи [9, с. 11-12].

Одним із важливих елементів застосування законодавства 3 протидії домашнього насильства є моніторинг та аналіз судової практики, пов'язаної $з$ домашнім насильством, оскільки саме через іï призму можна оцінити реальну ефективність законодавства та його здатність захистити жертв насильства та притягнути до відповідальності кривдника.

Значним недоліком при розгляді справ даної категорії є посилання судів на застарілі норми Закону України «Про попередження насильства в сім үі» від 15.11.2001 № 2789-III, який втратив чинність на підставі Закону України «Про запобігання та протидію домашньому насильству» від 07.01.2018 № 2229-VIII, а також положення статті 173-2 КУпАП, до котрої було внесено зміни згідно із Законом № 2229-VIII від 07.12.2017_[10].

Як приклад, можна навести Постанову Бориславського районного суду м. Борислав від 16.05.2019 № 647/1273/19, відповідно до якої розглядалася справа про притягнення особи до адміністративної відповідальності за ч.1 ст. 173-2 КУпАП, де було зазначено, що 08.05.2019 р., о 23:30 год., за місцем свого проживання, ОСОБА_1, перебуваючи в стані алкогольного сп'яніння, вчинила відносно своєї колишньої дружини (ОСОБА_2) насильство в сім'ї, а саме: нанесла тілесні ушкодження, висловлювалася щодо неї грубо, нецензурну лайку, погрожувала фізичною розправою, 
чим вчинила правопорушення, передбачене ч.1 ст. 173-2 КУпАП. У судовому засіданні колишній чоловік, провину у скоєному правопорушенні не визнав, пояснивши, що ОСОБА_2 не є його дружиною.

При встановленні фактів та відповідних правовідносин, суд зробив посилання на ст. 1 Закону України «Про попередження насильства в сім ї», та на ст. 64 Житлового Кодексу України, відповідно до якої ОСОБА_2 не вважається членом сім ї.

За цією справою суд дійшов висновку про відсутність складу адміністративного правопорушення [11].

Наступним прикладом є рішення у справі № 477/859/20 Жовтневого районного суду м. Миколаїв, у якому судом також помилково були застосовані нормативно-правові акти, які на момент розгляду справи та винесення постанови втратили чинність. Обставини справи: 21 травня 2020 р. до суду з Вітовського відділення поліції Корабельного ВП ГУНП у Миколаївській області надійшла справа про адміністративне правопорушення № 477/859/20 про притягнення ОСОБИ_1 до адміністративної відповідальності за вчинення адміністративного правопорушення, передбаченого ч.1 ст. 173-2 КУпАП.

Як вбачається 3 протоколу про адміністративне правопорушення від 11 травня 2020 р., серії ВАБ, № 328362, 11 травня 2020 р,. близько 13:00, ОСОБА_1 у стані алкогольного сп'яніння, перебуваючи за місцем проживання (АДРЕСА_1), висловлювалася на адресу колишньої дружини (ОСОБА_2) нецензурно, погрожувала фізичною розправою, чим вчинила в сім'ї насилля психологічного характеру.

При встановленні фактів та відповідних правовідносин суд посилається на ст. 3 Сімейного кодексу України та доходить висновку, що матеріали справи не містять доказів про перебування особи, яка притягується до адміністративної відповідальності, з ОСОБОЮ_2 в зареєстрованому шлюбі, а також того, що особи проживають однією сім'єю, ведуть спільне господарство.

Як результат, суд дійшов висновку про необхідність закриття провадження у справі за відсутністю в діях ОСОБИ_1 складу адміністративного правопорушення [11].

У наведених прикладах суди помилково посилаються на ст.173-2КУпАП у старій редакції та на положення Закону України «Про попередження насильства в сім “̈».

Окремої уваги в наведених прикладах заслуговує питання судів, які при розгляді справ про вчинення домашнього насилля та визначення «член сім'ї», посилаються на диспозиції ст. 64 Житлового Кодексу України та ст. 3 Сімейного Кодексу України. Так, відповідно до положень ч.2 ст. 3 Сімейного Кодексу України, сім'ю складають особи, які спільно проживають, пов'язані спільним побутом, мають взаємні права та обов'язки. Сімейний кодекс України не включає до членів сім'ї колишнє подружжя, навіть за умови їхнього спільного проживання [12]. Стаття 64 Житлового кодексу України визначає, що до членів сім'ї належать дружина, iї діти і батьки [13].

Зауважимо, що неоднозначне тлумачення терміна «член сім'ї» створило підстави для подання до Конституційного Суду України.

Тлумачення поняття «член сім’ї» дається в п.6 Рішення Конституційного Суду України від 03.06.1999 № 5-рп/99, у якому міститься роз' яснення з цього приводу. Конституційний Суд України виходить із об'єктивної відмінності його змісту залежно від галузі законодавства (п.6). Таким чином, на думку Конституційного Суду, 
визначити єдине поняття «член сім'ї», яке б мало застосовуватися в праві, неможливо, бо кожна галузь права тлумачить це поняття по-своєму, виокремлюючи ті чи інші ознаки сім'ї, що набувають певного значення для інших відносин.

Водночас, необхідно зазначити, що при розгляді справ судами про вчинення домашнього насильства, базовим є Закон України «Про запобігання та протидії домашньому насильству», у контексті якого термін «член сім'і»), окрім інших осіб, поширюється й на колишнє подружжя незалежно від факту їх спільного проживання.

Приклади судових проваджень ілюструють реалії, з якими стикаються жертви домашнього насильства в Україні, та неефективність державної політики в напрямі захисту жертв, надання їм допомоги та притягнення до відповідальності правопорушників.

У даному контексті також необхідно звернути увагу на позищію щодо незворотності дії в часі законів та інших нормативно-правових актів, що ії неодноразово висловлював Конституційний Суд України. Так, згідно з висновками щодо тлумачення змісту ст. 58 Конституції України, викладеними в рішеннях Конституційного Суду України від 13 травня 1997 № 1-зп, від 9 лютого 1999 № 1-рп/99, від 5 квітня 2001 № 3-рп/2001, від 13 березня 2012 № 6-рп/ 2012, закони та інші нормативноправові акти поширюють свою дію тільки на ті відносини, які виникли після набуття чинності законами чи іншими нормативно-правовими актами; дію нормативно-правового акту в часі треба розуміти так, що вона починається з моменту набрання цим актом чинності і припиняється із втратою ним чинності, тобто до події, факту застосовується той закон або інший нормативно-правовий акт, під час дії якого вони настали або мали місце.

При тому дія закону та іншого нормативно-правового акта не може поширюватися на правовідносини, які виникли і закінчилися до набрання чинності цим законом або іншим нормативно-правовим актом [14].

Висновки. У статті проведений огляд судових рішень про адміністративні правопорушення, передбачені ст. 173-2 КУпАП, які є доступними у Сдиному державному реєстрі судових рішень України. Автор не ставила за мету надати оцінку діям конкретних посадових осіб, однак в аналізі практики наводяться дані про номер справи та суд, який ії розглянув, оскільки ці відомості є загальнодоступними та відкритими.

У наведених, як приклад, справах про адміністративні правопорушення, передбачені ст. 173-2 КУпАП, судам перш за все необхідно посилатися на чинний Закон України «Про запобігання та протидію домашнього насильства». При встановленні фактів та відповідних правовідносин необхідно також посилатися на положення ст. 3 Закону України «Про запобігання та протидію домашнього насильства», де визначається коло осіб, які можуть визнаватись жертвами такого насилля. Саме такий підхід відповідатиме міжнародним та національним стандартам у сфері протидії домашньому насильству, а також забезпечить необхідний рівень захисту членів колишнього подружжя, інтимних партнерів, дітей свідків тощо.

\section{Використані джерела:}

1. Конвенщія Ради Свропи про запобігання насильству стосовно жінок і домашньому насиљству та боротьбу із цими явищами (Стамбульська конвенщія) Довідник для 
членів парламенту, 2013. 108 с. URL : https://rm.coe.int/1680096e45. (дата звернення: 05.11.2020).

2. Бандурка О. М. Оперативно-розшукова діяльність : підручник. Харків : ХНУВС, 2002. Ч. 1. С. 88.

3. Наконечна Г. Я. Суди як суб'єкти адміністративно-правових відносин : дис... канд. юрид. наук: 12.00.07. Харків, 2013. 220 с.

4. Про запобігання та протидію домашньому насильству: Закон України від 07. 12.2017 № 2229-VIII. URL : http:/ / zakon3.rada.gov.ua/laws/show/2229-19. (дата звернення: 05.11.2020).

5. Судовий розгляд справ, пов'язаних із вчиненням насильства в сім'їв Україні: проблеми відповідності міжнародним стандартам та шляхи вдосконалення : науково-практичний посібник / Євсюкова М. В., Христова Г. О., Шаповалова О. А. та ін. / за заг. ред. Шаповалової О. А., Павлиш С. О. Київ : ТОВ «Компанія «Ваіте», 2011. 196 с.

6. Матяж М. Як реагувати жертвам домашнього насиљства на недостатнюувагу 3 боку поліції? URL : https://www.radiosvoboda.org/a/30117262.html. (дата звернення: 05.11.2020).

7. В ізоляції, але не в безпеці. Допомога постраждалим від домашнього насильства в умовах карантину за підтримки UNFPA Україна. URL : https://ukraine.unfpa.org/uk/ isolationGBV. (дата звернення: 05.11.2020).

8. Домашнє насиљство під час карантину: страждають діти. URL : https://sheriffua.org/news/dnipro/domashnje-nasilstvo-pid-chas-karantinu-strazhdajut-diti. (дата звернення: 05.11.2020).

9. Розгляд справ стосовно жорстокого поводження з дітьми судами України: аналіз законодавства та практики його застосування. / Ахтирська Н. М., Кочемировська О.О., Христова Г. О. та ін. Київ : ТОВ «К.І.С.», 2010.124 с.

10. Кодекс України про адміністративні правопорушення: Закон України від 07. 12.1984. Відомості Верховної Ради УРСР. 1984. Додаток до № 51. Ст. 1123.

11. Єдиний державний реєстр судових рішень України. URL : http:/ /reyestr. court. gov.ua/Page/5. (дата звернення: 05.11.2020).

12. Сімейний кодекс України : Закон України від 10.01.2002 № 2947-III. Вidомост iВерховної Ради України. 2002. № 21-22. Ст. 135.

13. Житловий кодекс Української РСР: Закон України від 30.06 .1983 р. № 5464-Х Вiдомості Верховної Ради (ВВР). 1983. Додаток до № 28. Ст. 573.

14. Дія закону у часі: особливості правозастосовної практики Верховного Суду (на прикладі вирішення публічно-правових спорів) URL : https://bit.ly/3fNyykn. (дата звернення: 05.11.2020).

\section{References:}

1. Konventsiia Rady Yevropy pro zapobihannia nasylstvu stosovno zhinok i domashnomu nasylstvu ta borotbu iz tsymy yavyshchamy (Stambulska konventsiia) Dovidnyk dlia chleniv parlamentu. (2013) N. p. URL : https://rm.coe.int/1680096e45. [in Ukrainian].

2. Bandurka, O. M. (2002) Operatyvno-rozshukova diialnist : pidruchnyk. Kharkiv : KhNUVS, part. 1, 88. [in Ukrainian].

3. Nakonechna, H. Ya. (2013) Sudy yak sub'iektyadministratyvno-pravovykh vidnosyn. Candidate's thesis. Kharkiv. [in Ukrainian].

4. Pro zapobihannia ta protydiiu domashnomu nasylstvu: Zakon Ukrainy vid 07.12.2017 № 2229-VIII. (2017) N. p. URL: http:/ / zakon3.rada.gov.ua/laws/show/2229-19. [in Ukrainian]. 
5. Sudovyirozghliad sprav, pov'iazanykh z vchynenniamnasylstva v sim'i v Ukraini: problemy vidpovidnosti mizhnarodnym standartam ta shliakhy vdoskonalennia : naukovopraktychnyiposibnyk (2011) Ievsiukova, M. V., Khrystova, H. O., Shapovalova, O. A. (Eds.) et al. / Shapovalova, O. A., Pavlysh, S. O. (Ed.) Kyiv : TOV «Kompaniia «Vaite». [in Ukrainian].

6. Matiazh, M. Yak reahuvaty zhertvam domashnohonasylstva na nedostatniuuvahu $\mathrm{z}$ boku politsii? N. d. N. p. URL : https://www.radiosvoboda.org/a/30117262.html. [in Ukrainian].

7. V izoliatsii, ale ne v bezpetsi. Dopomoha postrazhdalym vid domashnoho nasylstva $\mathrm{v}$ umovakh karantynu za pidtrymky UNFPA Ukraina. N. d. N. p. URL : https://ukraine. unfpa. org/uk/isolationGBV. [in Ukrainian].

8. Domashnie nasylstvo pid chas karantynu: strazhdaiut dity. N. d. N. p. URL : https:// sheriffua.org/news/dnipro/domashnje-nasilstvo-pid-chas-karantinu-strazhdajut-diti. [in Ukra inian].

9. Rozghliad sprav stosovno zhorstokoho povodzhennia z ditmy sudamy Ukrainy: analiz zakonodavstva ta praktyky yoho zastosuvannia. (2010) Akhtyrska, N. M., Kochemyrovska, O. O., Khrystova, H. O. (Eds.) et al. Kyiv : TOV «K.I.S.». [in Ukrainian].

10. Kodeks Ukrainy pro administratyvnipravoporushennia: Zakon Ukrainyvid 07.12.1984 (1984) Vidomosti Verkhoonoi Rady URSR - Information of the Verkhoona Rada of the USSR, dod. N51, art. S1123. [in Ukrainian].

11. Yedynyi derzhavnyi reiestr sudovykh rishen Ukrainy. N. d. N. p. URL : http://reyestr. court.gov.ua/Page/5. [in Ukrainian].

12. Simeinyi kodeks Ukrainy : Zakon Ukrainyvid 10.01.2002 № 2947-III. (2002) Vidomosti Verkhoonoi Rady Ukrainy -Vidomosti Verkhoonoi Rady Ukraine, 21-22, art. 135. [in Ukrainian].

13. Zhytlovyi kodeks Ukrainskoi RSR: Zakon Ukrainy vid 30.06.1983 r. № 5464-X. (1983) Vidomosti Verkhoonoi Rady (VVR) - Vidomosti Verkhoonoi Rady, dod. N 28, art. 573. [in Ukrainian].

14. Diia zakonu u chasi: osoblyvosti pravozastosovnoi praktyky Verkhovnoho Sudu (na prykladi vyrishennia publichno-pravovykh sporiv) N. d. N. p. URL: https:/ / bit.ly/3fNyykn. [in Ukrainian].

Стаття надіӥшла до редколегї 05.11.2020

Малиновская Т. Н., кандидат юридических наук, доцент, ведущий научный сотрудник научно-исследовательской лаборатории по проблемам противодействия преступности Харьковского национального университета внутренних дел (г. Харьков, Украина)

\section{ПРОБЛЕМЫ ОБЕСПЕЧЕНИЯ ЭФФЕКТИВНОЙ СУДЕБНОЙ ЗАЩИТЫ ЖЕРТВ ДОМАШНЕГО НАСИЛИЯ ПО ДЕЛАМ ОБ АДМИНИСТРАТИВНЫХ ПРАВОНАРУШЕНИЯХ, ПРЕДУСМОТРЕННЫХ СТАТЬЁЙ 173-2 КУобАП}

В научной статье рассмотрены проблемные вопросы обеспечения эффективной судебной защиты жертв домашнего насилия по делам об административных правонарушениях, предусмотренных ст. 173-2 КУобАП. Указано, что домашнее насилие является комплексной проблемой, нарушает целый ряд прав и свобод человека. Отмечено, что Украина принадлежит к тем странам, в которых еще отсутствует эффективная система защиты и оказания помощи жертвам домашнего насилия. 
В научной статье проведен анализ судебной практики по делам об административных правонарушениях, предусмотренных ст. 173-2 КУобАП.

Ключевые слова: домашнее насилие, права человека, административная ответственность, суд, защита.

Malynovska T., Candidate of Jurisprudence, Associate Professor, Leading Researcher, Research Laboratory for Combating Crime, Kharkiv National University of Internal Affairs (Kharkiv, Ukraine)

\section{PROBLEMS OF ENSURING EFFECTIVE JUDICIAL PROTECTION FOR DOMESTIC VIOLENCE VICTIMS IN CASES ON ADMINISTRATIVE OFFENSES STIPULATED BY THE ARTICLE 173-2 OF THE CODE OF UKRAINE ON ADMINISTRATIVE OFFENSES}

The author of the scientific article has studied the problematic issues of ensuring effective judicial protection of domestic violence victims in cases on administrative offenses stipulated by the Art. 173-2 of the Code of Ukraine on Administrative Offenses.

It has been emphasized that domestic violence is a comprehensive problem that affects and violates a number of human rights and freedoms, in particular, to life, liberty, inviolability, living free from degrading honor and dignity, etc. Therefore, every civilized country, to overcome this difficult problem, must implement an effective comprehensive system on combating domestic violence, which consists of three main elements - prevention of violence, prosecution of perpetrators and provision of assistance and protection to victims of domestic violence.

It has been noted that Ukraine is one of those countries that still has no effective system of protection and provision of assistance to victims of domestic violence. This problem has been repeatedly pointed out by various international organizations, including the Council of Europe. The ineffectiveness of the system of protection and provision of assistance to victims of domestic violence, as well as the entire system of combating domestic violence is not due so much to the imperfection of national legislation, but is due to ineffective administration of the law by law enforcement and judicial agencies of Ukraine.

The author of the scientific article has analyzed the court practice in cases on administrative offenses stipulated by the Art. 173-2 of the Code of Ukraine on Administrative Offenses, the decisions of which are placed in open access of the Unified State Register of Court Decisions of Ukraine; the main problems of their judicial consideration have been defined.

It has been concluded that the role of the court in ensuring the safety and protection of victims from further unlawful encroachments is extremely important. It can be achieved through the proper application of the norms of national law in combating domestic violence, in particular by bringing perpetrators to justice, restricting offenders' access to victims, establishing harm compensation to victims, inflicted by the offender to the victim by illegal actions, etc.

Keywords: homeviolence, humanrights, administrativeresponsibility, court, defence. 